\title{
GAGASAN PEMBENTUKAN PERADILAN KELUARGA DI INDONESIA
}

\author{
Firman Freaddy Busroh \\ Sekolah Tinggi Ilmu Hukum Sumpah Pemuda Palembang \\ Jl. Animan Achyat (d/h. Jl.Sukabangun 2) Nomor 1610 Kel.Sukabangun Kec.Sukarami Kota \\ Palembang, Provinsi Sumatera Selatan, Kode Pos 30151 \\ firmanbusroh@stihpada.ac.id
}

\begin{abstract}
Many family cases in Indonesia such as divorce, inheritance disputes, probate, grant, joint treasury settlement, adoption of children, mixed marriage, domestic violence, and others need right and fast solution. These cases are currently resolved through Religious Courts for Muslims and General Courts for non-Muslims. This dualism of justice often generates the dualism of contradictory decisions, unclear competence. It is also questionable that the Religious Courts only hear Muslim plaintiffs, whereas the recognized Religion in Indonesia is not only Islam but other religions, and beliefs that are guaranteed protection by the state. It is necessary to establish a special family judiciary to try family affairs that give more guarantee the legal certainty and lighten duties of the general court.
\end{abstract}

Keywords: Family Case; Family Courts; Judicial Competence

\begin{abstract}
Abstrak
Maraknya kasus-kasus keluarga di Indonesia seperti perceraian, sengketa waris, wasiat, hibah, penyelesaian harta bersama, pengangkatan anak, perkawinan campuran, kekerasan dalam rumah tangga, dan lainnya membutuhkan solusi yang tepat dan cepat. Kasus-kasus tersebut saat ini diselesaikan melalui jalur Peradilan Agama bagi muslim dan Peradilan Umum bagi non muslim. Adanya dualisme Peradilan ini sering melahirkan dualisme putusan yang bertentangan, tidak jelasnya kompetensi mengadili. Hal yang patut dipertanyakan juga bahwa Peradilan Agama hanya menyidangkan pemohon/penggugat yang beragama Islam padahal agama yang diakui di Indonesia tidak hanya Islam tetapi juga agama lainnya dan kepercayaan yang dijamin perlindungannya oleh negara. Untuk itu, perlu pendirian Peradilan keluarga yang khusus mengadili urusan keluarga agar lebih menjamin kepastian hukum dan meringankan tugas-tugas Peradilan Umum.
\end{abstract}

Kata kunci: Kasus Keluarga; Peradilan keluarga; Kompetensi Peradilan

\section{A. Pendahuluan}

Banyaknya kasus-kasus keluarga di Indonesia perlu mendapat perhatian dari pemerintah. Hal ini bisa kita lihat betapa banyak masyarakat yang antri menunggu giliran di Pengadilan Agama dan Pengadilan Negeri Umum. Apalagi di Pengadilan Umum banyak sekali perkara-perkara yang ditangani selain perkara keluarga, misalnya perkara pidana umum, perkara korupsi, perkara perdata, penetapan kewarganegaran dan perkara-perkara lain. Banyaknya perkaraperkara tersebut tentu menambah tugas Pengadilan. Akibatnya menambah panjang antrian pemohon/penggugat yang ingin menyelesaikan permasalahan keluarga di Pengadilan.

Kasus-kasus keluarga di Indonesia cukup tinggi dan beragam jenisnya. Adapun jenis-jenis kasus keluarga antara lain perceraian, sengketa waris, wasiat, hibah, penyelesaian harta bersama, pengangkatan anak, pencabutan kekuasaan wali, perkawinan campuran, kekerasan dalam rumah tangga. Kasus keluarga yang paling marak adalah perceraian. Berdasarkan data yang dirilis oleh Badan Pusat Statistik tahun 2012-205 terdapat peningkatan jumlah kasus perceraian. Hal ini bisa dilihat pada tahun 2012 angka perceraian di Indonesia 346.480 
kasus dan tahun 2015 angka perceraian naik menjadi 347.256 kasus (Badan Pusat Statistik, 2015).

Trend kasus perceraian memang menjamur dan makin banyak jumlah dari tahun-tahun. Ada beberapa faktor penyebabnya antara lain kurangnya komunikasi, perselingkungan, ketimpangan perekonomian, campur tangan keluarga, kekerasan dalam rumah tangga, perselisihan dalam keluarga. Kesemua kasus-kasus tersebut disidangkan di Pengadilan Agama bagi pemohon/penggugat muslim dan di Pengadilan Negeri/Umum bagi pemohon/penggugat non muslim.

Adanya kompetensi absolut mengadili kedua pengadilan tersebut seringkali menimbulkan pertanyaan bagi masyarakat yang awam tentang ilmu hukum. Masih banyak masyarakat yang mengira bahwa Pengadilan Agama menyidangkan kasuskasus keluarga untuk semua agama. Ada 6 (enam) agama yang diakui di Indonesia yaitu Islam, Kristen Katolik, Kristen Protestan, Budha, Hindu, Kong $\mathrm{Hu} \mathrm{Cu}$ dan beberapa kepercayaan/aliran yang diakui keberadaan oleh negara. Akan tetapi kenyataan bahwa Pengadilan Agama hanya menyidangkan kasus-kasus keluarga bagi muslim, sedangkan kasus-kasus keluarga non muslim disidangkan di Pengadilan Negeri/ Umum. Hal ini tentunya perkataan agama pada Peradilan Agama menjadi ambigu bila bersumber pada kebijakan pemerintah yang mengakui keberadaan 6 (enam) agama dan kepercayaan. Hal ini juga menimbulkan kesan diskriminasi terhadap umat-umat beragama di Indonesia.

Bila berkaca kepada negara-negara lain seperti Australia, Amerika, Inggris tidak mengenal Pengadilan Agama (Religion Court), akan tetapi mengenal Pengadilan Keluarga (Familiy Court). Pengadilan Keluarga di negara negara tersebut mengadili kasus-kasus yang berkaitan dengan masalah keluarga, termasuk kenakalan remaja, sedangkan di Indonesia masih disidangkan di Pengadilan Negeri/Umum. Akhirnya, Hakim pada Pengadilan Negeri/Umum dituntut untuk serba bisa, padahal hakim yang mengadili masalah keluarga adalah hakim yang khusus menguasai masalah keluarga.
Permasalahan keluarga adalah permasalahan banyak terjadi di Indonesia. Pengadilan Keluarga yang khusus mengadili masalah-masalah keluarga sudah mendesak untuk dibentuk karena kebutuhan. Pengadilan Keluarga harus menjadi Pengadilan yang bisa menyelesaikan kasus-kasus keluarga lebih terfokus dan tepat sasaran. Selain itu juga persoalan pembagian waris masih jadi kendala karena seringkali diadili di Pengadilan Agama dan Pengadilan Umum/Negeri yang akhirnya menimbulkan ketidakpastian hukum. Untuk itu, sudah saatnya Indonesia memiliki Pengadilan Keluarga yang khusus menangani kasuskasus keluarga.

\section{B. Pembahasan}

Pada saat seorang pria dan seorang wanita ingin hidup bersama, maka akan diikat oleh ikatan yang sah berupa perkawinan yang dilangsungkan menurut hukum agama dan negara. Pernikahan tersebut dilakukan menurut adat istiadat masing-masing. Adapun pelaksanaan pernikahan di Indonesia diatur dalam Undang-Undang Nomor 1 Tahun 1974 tentang Perkawinan. Setelah pasangan tersebut menikah secara sah menurut agama dan tercatat sering kali timbul masalah yang pada akhirnya membutuhkan lembaga Pengadilan untuk menyelesaikan permasalahan keluarga tersebut.

Masalah-masalah keluarga di Indonesia diadili oleh 2 (dua) Pengadilan, yaitu: Pengadilan Agama dan Pengadilan negeri/Umum. Peradilan Agama diatur didalam Undang-Undang Nomor 3 Tahun 2006 yang merupakan perubahan dari Undang-Undang Nomor 7 Tahun 1989. Jenisjenis perkara yang diadili oleh Pengadilan Agama, antara lain: izin beristri lebih dari seorang, izin melangsungkan perkawinan bagi orang yang belum berusia 21 tahun, dispensasi kawin, pencegahan perkawinan, penolakan perkawinan, pembatalan perkawinan, gugatan kelalaian atas kewajiban suami dan istri, perceraian karena talak, gugatan perceraian, penyelesaian harta bersama, penguasaan anak-anak, penentuan kewajiban memberi biaya penghidupan oleh suami kepada bekas istri, pencabutan kekuasaan wali, pencabutan kekuasaan orang 
tua, pengangkatan anak, penunjukan wali dalam hal seorang anak belum cukup umur 18 tahun, penetapan asal-usul seorang anak, penolakkan pemberian keterangan untuk melakukan perkawinan campuran, penentuan ahli waris, penentuan harta peninggalan, pembagian harta peninggalan, pemberian wasiat, pemberian hibah, pemberian wakaf, pemberian zakat, infak, sodaqoh, dan perekonomian syariah.

Permasalahan keluarga bagi non muslim disidangkan di Pengadilan Negeri/Umum. Jenis-jenis perkara keluarga yang disidangkan Pengadilan negeri, antara lain: perkawinan, perceraian, pengangkatan anak, pemutusan kekuasaan orang tua atau wali, pembagian waris, pembuatan wasiat, penyelesaian harta bersama, penentuan ahli waris, pembatalan pernikahan. Di samping itu, beberapa kasus yang seharusnya masuk kategori kasus keluarga akan tetapi disidangkan di Pengadilan Umum/negeri, misalnya kekerasan dalam rumah tangga, pencabulan anak di bawah umur, pemerkosaan dalam keluarga, kenakalan anak. Kasus-kasus keluarga tersebut semestinya diselesaikan secara khusus oleh Pengadilan keluarga dan diadili oleh hakim yang khusus memiliki pengetahuan mengenai hukum keluarga.

Ada beberapa negara yang memiliki Pengadilan keluarga (Family Court) dimana salah satu negara yang memiliki Pengadilan keluarga, yaitu Australia. Pemerintahan Australia memiliki sistim Peradilan keluarga yang mampu membantu masyarakat. Untuk membantu penyelesaian permasalahan keluarga, maka Pengadilan keluarga di Australia menyediakan pos bantuan hukum. Pos bantuan hukum ini dikelola oleh tiga pihak yaitu: pihak Universitas, LSM, dan Pemerintah. LSM di Australia memiliki tenaga advokat yang bisa membantu masyarakat untuk menyelesaikan permasalahan keluarga.

Pengadilan keluarga juga dapat ditemui dibeberapa negara, seperti Amerika, Inggris, India, dan Hongkong. Mekanisme Pengadilan keluarga di Amerika di pimpin oleh hakim tunggal tanpa dewan juri. Sebelum kasus keluarga naik ke Pengadilan, maka pemohon menggunakan upaya mediasi. Sumber hukum yang digunakan Pengadilan keluarga di Amerika diatur di dalam hukum keluarga (family law). Di Inggris Pengadilan keluarga terdiri dari dua Pengadilan yaitu Pengadilan Tinggi Divisi Keluarga dan Pengadilan Keluarga. Pengadilan keluarga dibentuk berdasarkan Undang-Undang Kejahatan dan Pengadilan Tahun 2013 dan Undang-Undang Anak Tahun 1989. Keberadaan UndangUndang Hukum Keluarga sejak ada tahun 1996 di Inggris. Pengadilan keluarga di India dibentuk sejak tanggal 14 september 1984 berdasarkan Undang-Undang Pengadilan Keluarga. Pengadilan keluarga berada di bawah Pengadilan Tinggi di India, jenis perkara yang diadili: perkawinan, perceraian, restitusi hak suami istri, deklarasi validitasi status perkawinan, perwalian seseorang, hak asuh. Pengadilan keluarga di Hongkong mengutamakan upaya mediasi untuk membantu para pasangan berpisah/bercerai dengan kesepakatan yang saling menguntungkan serta pengaturan hak asuh anak dan penentuan pemberian biaya hidup. Pengadilan keluarga di Hongkong menggunakan peran mediator untuk menyelesaikan kasus-kasus keluarga.

Dari beberapa negara tersebut di atas, seperti Australia, Amerika, Inggris, India, Hongkong, telah memiliki Pengadilan keluarga. Bila dicermati jenis-jenis perkara yang diadili pengadilan keluarga di negaranegara tersebut tidak sekompleks perkaraperkara yang ada di Indonesia. Kompleksnya perkara yang ada di Indonesia salah satu penyebabnya adalah sistim hukum campuran yang dianut di Indonesia yaitu: campuran antara sistim Civil Law, Common Law, Islamic Law. Selain itu, juga kemajemukan bangsa Indonesia yang terdiri atas beberapa Suku, Ras, Agama, dan Adat Istiadat. Akan tetapi, hal tesebut bukanlah menjadi faktor penghambat untuk membentuk Pengadilan keluarga, melainkan suatu keharusan untuk membentuk Pengadilan keluarga, mengingat kemajemukan bangsa Indonesia.

Sistem hukum di Indonesia merupakan suatu kesatuan yang terdiri dari unsur-unsur atau elemen yang saling berinteraksi satu sama lain. Lawrence M. Friedman mengemukakan empat fungsi sistem hukum: Pertama, sebagai bagian dari sistem kontrol 
sosial (social control) yang mengatur perilaku manusia. Kedua, sebagai sarana untuk menyelesaikan sengketa (dispute settlement). Ketia, sistem hukum memiliki fungsi sebagai enginnering function. Keempat, hukum sebagai social maintenance, yaitu fungsi yang menekankan peranan hukum sebagai pemeliharaan "status quo" yang tidak menginginkan perubahan.

Menurut Friedman ada tiga element dari sistem hukum, yaitu legal structure, legal substance dan legal culture. Legal structure adalah menyangkut lembaga-lembaga yang berwenang membuat dan melaksanakan peraturan perundang-undangan (lembaga Pengadilan dan lembaga legislatif). Legal substance yaitu materi atau bentuk dari peraturan perundang-undangan, dan Legal culture adalah apa yang disebutkan sebagai sikap orang terhadap hukum dan sistem hukum, yaitu menyangkut kepercayaan akan nilai, pikiran atau ide harapan mereka (Friedman, 1984).

Struktur hukum yang baik tidak akan berjalan dengan baik jika tidak ditunjang oleh adanya substansi hukum yang baik pula. Demikian pula substansi hukum yang baik tidak akan dapat dirasakan manfaatnya kalau tidak ditunjang oleh struktur hukum yang baik. Selanjutnya struktur dan substansi hukum yang baik tidak akan dapat dirasakan eksistensinya kalau tidak didukung oleh budaya hukum masyarakat dengan baik. Hukum akan berjalan dan berperan baik apabila ketiga aspek subsistem yaitu struktur, substansi dan budaya hukum itu saling berinteraksi dan memainkan peranan sesuai dengan fungsinya, sehingga hukum akan berjalan secara serasi dan seimbang serta sesuai dengan fungsinya.

Di Indonesia terdapat 4 (empat) lingkungan Peradilan sebagai pelaksana fungsi dan kewenangan kekuasaan kehakiman, yaitu Peradilan Umum, Peradilan Agama, Peradilan tata usaha negara, dan Peradilan militer. Batas kekuasaan antara masing-masing lingkungan ditentukan oleh bidang yuridiksi yang dilimpahkan oleh undang-undang dalam batas-batas yuridiksi tersebut masing-masing melaksanakan fungsi mengadili.

Tujuan penentuan batas kewenangan kompetensi setiap lingkungan Peradilan, agar terbina suatu pelasanaan kekuasaan kehakiman yang tertib antara masing-masing lingkungan Peradilan. Tidak saling berebut kekuasaan di antara lingkungan Peradilan Umum hanya berkompetensi memeriksa dan memutus perkara pidana Umum, perdata adat, dan perdata barat. Kewenangan Peradilan tata usaha negara hanya meliputi memeriksa dan memutus perkara berkaitan dengan keputusan yang dikeluarkan oleh pejabat tata usaha negara. Kompetensi absolut Peradilan militer hanya berwenang mengadili perkara tindak pidana militer dan tidak pidana Umum yang dilakukan oknum anggota TNI, sedangkan kompetensi lingkungan Peradilan Agama memeriksa dan memutuskan dalam perkara perceraian dan pembagian harta waris bagi yang beragama Islam(Lisdiyono, 2016).

Dengan adanya pembatasan kompetensi masing-masing Peradilan tersebut akan memberikan ketentraman dan kepastian hukum bagi masyarakat pencari keadilan mengenai lingkungan Peradilan mana yang berwenang memeriksa dan memutuskan sengketa yang sedang dihadapinya sehingga jelas ke mana mereka akan mengajukan perkara. Lembaga Peradilan sendiri terkadang belum bisa memberikan rasa keadilan bagi pihak-pihak yang berperkara di muka Pengadilan.

Pengertian mengenai keadilan itu sendiri berasal dari kata dasar "adil", merupakan perasaan yang paling luas mendalam dalam tata tertib hubungan manusia berdasarkan prinsip Umum yang diterapkan. Aristoteles menggambarkan keadilan sebagai benuk persamaan atau "equality" yaitu prinsip di mana suatu kasus yang sama seharusnya diperlukan dalam cara yang sama dan kasus yang berbeda diperlukan dengan cara yang berbeda. Keadilan berlawanan dengan :

1. Pelanggaran hukum, penyimpangan, ketidaktetapan, ketidakpastian, keputusan yang tidak terduga, tidak dibatasi oleh peraturan;

2. Sikap memihak dalam penerapan aturan; dan

3. Aturan yang memihak atau sewenang- 
wenang, melibatkan diskriminasi yang tidak berdasarkan perbedaan yang tidak relevan.

Keadilan atau "justice" dapat dibedakan dalam dua (2) bentuk, yaitu:

1. Keadilan Distibutif, yang menyatakan bahawa keadilan berkaitan dengan penghargaan dan kekayaan yang sama yang harus diterima oleh orang yang sama dalam kondisi kedudukannya yang sama dalam Negara;

2. Keadilan Korektif, keadilan yang berlaku dalam suatu hubungan perdata. Dalam keadilan korektif tidak ada perbedaan dalam arti kedudukan seseorang dalam negara. Setiap orang yang menyebabkan orang lain menderita kerugian, harus memulihkan (menanggung) kerugian tersebut.

Tidak salah apabila ada yang mengatakan bahwa semua orang merupakan bagian dari pencari keadilan. Setiap orang berharap menyaksikan hakim berbuat sebagaimana mestinya dan berimbang, setiap orang berharap melihat Pengadilan yang berhasil mencapai hasil yang benar, tetapi terlalu sering kita malah kecewa, lebih mudah mencari keadilan daripada menemukan keadilan(Rawls, 2001).

Untuk menemukan keadilan, maka salah satu lembaga yang diberikan tugas adalah lembaga Peradilan. Akan tetapi, lembaga Peradilan nyatanya belum sepenuhnya mewujudkan asas Peradilan sedernana, cepat dan biaya ringan. Menurut Sudikno Mertokusumo pengertian asas sederhana, cepat, dan biaya ringan, yaitu: (Mertokusumo, 2002)

1. Kata cepat dapat diartikan dalam proses Peradilan, terlalu banyak formalitas yang merupakan hambatan bagi jalannya perdilan. Dalam hal ini bukan hanya jalannya Peradilan dalam pemeriksaan di muka persidangan saja, tetapi juga penyelesaian berita acara pemeriksaan di persidangan sampai dengan penandatanganan oleh hakim dan pelaksanaannya. Tidak jarang perkara tertunda-tunda sampai bertahun-tahun karena saksi tidak datang atau para pihak bergantian tidak datang, bahkan perkaranya sampai dilanjutkan oleh para ahli warisnya.

2. Asas sederhana adalah acara yang jelas, mudah difahami dan tidak berbelitbelit, dan cukup one stop service (penyelesaian sengketa cukup diselesaikan melalui satu lembaga Peradilan). Semakin sedikit dan sederhana formalitas-formalitas yang diwajibkan atau diperlukan dalam beracara di muka Pengadilan, semakin baik. Terlalu banyak formalitas yang sukar difahami, sehingga memungkinkan timbulnya bebagai penfsiran, kurang menjamin adanya kepastian hukum dan menyebabkan keengganan atau ketakutan untuk beracara di muka Pengadilan.

3. Ditentukan biaya ringan dalam beracara di Pengadilan atau terpikul atau dijangkau oleh rakyat. Biaya yang tinggi kebanyakan menyebabkan pihak yang berkepentingan enggan untuk mengajukan tuntutan hak kepada Pengadilan.

Selain persoalan di atas, ada beberapa kasus muncul karena pelanggaran kompetensi Peradilan. Hal ini disebabkan masih abu-abu kompetensi absolut yang tidak secara tegas mengaturnya. Hal ini disebabkan karena beberapa peraturan perundangundangan hukum di Indonesia masih mengadopsi produk hukum Belanda.

Bila melihat kilas balik sejarah pembentukan Peradilan Agama di Indonesia, maka pembentukan Peradilan Agama di Indonesia memang tidak bisa dilepaskan dari sejarah perjuangan para Ulama, Tokoh Agama serta pegiat-pegiat kemerdekaan saat itu. Benih-benih pembentukan Peradilan Agama di Indonesia sudah dikenal sejak Islam masuk Indonesia pada abad ke-7 Masehi. Pada era tersebut hukum Islam mulai berkembang di wilayah nusantara bersamasama dengan hukum adat yang diperkenalkan melalui ajaran-ajaran yang disampaikan oleh para ulama. Latar belakang historis adanya keprihatinan para ulama dan tokoh Agama terhadap pemberlakukan syariat Hukum Islam. Pembentukannya dapat dibagi tiga 
periode antara lain:

1. Tahkim kepada Muhkam. Ketika pemeluk Agama Islam masih sedikit, sering terjadi perselisihan atau sengketa diantara masyarakat yang perlu untuk diselesaikan dengan cara bertahkim kepada guru yang dianggap mampu dan berilmu Agama. Orang yang bertindak sebagai hakim disebut Muhkam.

2. Periode Ahlul Hilli Wal Akhdi. Pada saat penganut Agama Islam telah terorganisir dalam kelompok masyarakat yang teratur, maka posisi hakim atau khodi dilakukan secara pemilihan dan bai'at oleh ahlul hilli wal akhdi yaitu pengangkatan seseorang yang dipercaya oleh majelis atau kumpulan orang-orang terkemuka dalam masyarakat.

3. Periode Tauliyah. Ketika kelompok masyarakat Islam berkembang menjadi kerajaan Islam, maka pengangkatan jabatan hakim atau khodi dilakukan dengan pemberian tauliyah yaitu pengembalian atau pendelegasian kekuasaan dari penguasa.

Ada beberapa istilah atau nama untuk Pengadilan Agama pada masa itu antara lain:

1. Di Aceh disebut Mahkamah Syariah Jaumpa.

2. Di Sumatra Utara disebut Mahkamah Majelis Syara.

3. Di Bima (NTB) disebut Badan Hukum Syara.

4. Di Kerajaan Mataram disebut Pengadilan Syurambi

Pada tanggal 4 Maret 1620 dikeluarkan Instruksi di daerah yang dikuasai penjajah Belanda untuk diberlakukan hukum sipil Belanda. Dengan berlakunya hukum perdata Islam diakui oleh VOC tanggal 25 Mei 1760 yaitu berupa suatu kumpulan aturan hukum perkawinan dan hukum kewarisan menurut hukum Islam untuk dipergunakan pada Pengadilan VOC dan dipakai di daerahdaerah lain yaitu Cirebon, Semarang dan Makasar. Pada tahun 1854 pemerintah Belanda mengeluarkan kebijakan yang dituangkan dalam "Reglement op het beleid der Regeerings van Nederlandsch Indie" disingkat menjadi "Regeerings reglement" yang menegaskan berlakunya undangundang atau hukum Islam bagi orang Islam Indonesia. Selanjutnya tahun 1992 Regeerings reglement diubah menjadi Wet op the staats inrichting van nederlands indie sehingga terjadi perubahan pada struktur kelembagaan Peradilan Agama pada saat itu.

Pada masa pemerintahan penjajahan Jepang, lembaga Peradilan Belanda yang sudah ada pada masa penjajahan Belanda tetap berdiri dan dibiarkan pada bentuknya semula. Perubahan yang dilakukan terhadap lembaga ini hanya mengubah nama saja yaitu sooryoo hooin untuk Pengadilan Agama dan kaikyoo kootoo hooin untuk Mahkamah Islam tinggi (Pengadilan tinggi Agama).

Setelah kemerdekaan Indonesia Peradilan Agama semakin diperkuat dan dikukuhkan pondasinya melalui konstitusi Indonesia yaitu Undang-undang Dasar 1945. Di dalam pasal 24 ayat (1) Undang-undang Dasar 1945 disebutkan bahwa kekuasaan kehakiman dilaksanakan oleh sebuah Mahkamah Agung dan badan kehakiman menurut undang-undang. Dalam penjelasannya Peradilan Agama adalah salah satu lingkungan Peradilan yang dimaksud. Pada tahun 1948 dikeluarkan Undang-undang Nomor 19 tahun 1948 tentang susunan dan kekuasaan badan kehakiman yang menyusun macam-macam Peradilan Menteri Agama RI pernah mengeluarkan Surat Keputusan Menteri Agama Nomor 10 tahun 1963 yang memberikan wewenang dan kewajiban kepada jawatan Peradilan Agama untuk melaksanakan tugas-tugas Peradilan Agama di tingkat kasasi. Setelah berlaku Undangundang Nomor 14 tahun 1970 tentang Pokok Kekuasaan Kehakiman, maka Surat Keputusan Menteri Agama tersebut dicabut dengan Surat Keputusan Menteri Agama Nomor 28 tahun 1972. Didalam Undangundang Nomor 14 tahun 1970 tentang Pokok Kekuasaan Kehakiman dinyatakan:

1. Prinsip Peradilan dilakukan "Demi keadilan berdasarkan Ketuhanan yang Maha Esa" serta proses Peradilan yang menjunjung asas sederhana, cepat dan biaya ringan.

2. Kekuasaan kehakiman dilakukan oleh 
beberapa Pengadilan dalam lingkungan Mahkamah Agung antara lain Pengadilan Umum, Pengadilan Agama, Pengadilan Tata Usaha Negara dan Pengadilan Militer

3. Upaya hukum Kasasi merupakan wewenang Mahkamah Agung untuk semua lingkungan peradilan.

4. Badan-badan peradilan tetap berada di bawah kekuasaan masing-masing departemen.

5. Susunan kekuasaan dan acara dari badan-badan peradilan tersebut diatur dalam undang-undang tersendiri

Pada tahun 1985 dikeluarkan UndangUndang Nomor 14 tahun 1985 tentang Mahkamah Agung. Di dalam Pasal 1 ditetapkan bahwa Mahkamah Agung adalah lembaga tinggi negara sebagaimana dimaksud dalam Ketetapan Majelis Permusyawaratan Rakyat Republik Indonesia No. III MPR/1978. Dalam Pasal 2 disebutkan bahwa Mahkamah Agung adalah pengadilan negara tertinggi dari semua lingkungan Peradilan. Pada tahun 1989 lahirlah UndangUndang Nomor 7 Tahun 1989 tentang Peradilan Agama. Pasca berlakunya undnagundang tersebut dikeluarkan tiga peraturan antara lain: a) Surat Edaran Mahkamah Agung Nomor 1 tahun 1990, tanggal 12 Maret 1990 tentang petunjuk pembuatan penetapan sesuai pasal 84 ayat 4 Undang-Undang Nomor 7 Tahun 1989. B) Surat edaran Menteri Agama No. 2 tahun 1990 tentang Petunjuk Pelaksanaan Undang-Undang Nomor 7 Tahun 1989, c) Instruksi Presiden Nomor 1 Tahun 1991 tentang Penyebarluasan Kompilasi Hukum Islam (KHI). Di era reformasi terjadi perubahan terhadap Undang-Undang Nomor 7 Tahun 1989 dengan diubah menjadi Undang-Undang Nomor 3 Tahun 2006 dan perubahan kedua diatur di dalam Undang-Undang Nomor 50 Tahun 2009(Jaya, 2009).

Pada saat ini pemerintah mengakui keberadaan agama-agama lain selain Islam. Pengakuan pemerintah tersebut tercermin di dalam Pasal 28 E ayat (1) dan Pasal 29 ayat (2) Amandemen UUD 1945 yang menjamin kebebasan memeluk agama dan kepercayaan. Beberapa peraturan perundang-undang juga menyebutkan pengakuan terhadap 6 (enam) agama, yaitu Islam, Kristen Katolik, Kristen Protestan, Budha, Hindu, Kong $\mathrm{Hu} \mathrm{Cu}$ dan kepercayaan lainnya. Dengan adanya pengakuan tersebut, maka timbul ambigu bahwa Peradilan Agama hanya dikhususkan bagi umat muslim. Bila memang pemerintah mengakui agama-agama lain selain Islam, maka Peradilan Agama harus bisa mengakomodasi urusan agama masingmasing tersebut. Untuk itu, solusi jalan tengah yaitu dengan membentuk Peradilan Keluarga yang khusus mengadili permasalahan keluarga. Lagipula dengan membentuk Peradilan Keluarga akan mempertegas kompetensi absolut untuk mengadili suatu perkara yang berkaitan dengan urusan keluarga. Dengan adanya kekhususan tersebut, maka semua perkara yang menyidangkan permasalahan keluarga dapat dilimpahkan kepada Peradilan Keluarga sehingga meringankan beban Peradilan Umum yang hampir menangani semua perkara baik pidana Umum, pidana khusus, perdata Umum dan perdata khusus.

\section{Simpulan}

Permasalahan keluarga adalah permasalahan banyak terjadi di Indonesia. Pengadilan Keluarga yang khusus mengadili masalah-masalah keluarga sudah mendesak untuk dibentuk karena kebutuhan. Pengadilan Keluarga harus menjadi Pengadilan yang bisa menyelesaikan kasus-kasus keluarga lebih terfokus dan tepat sasaran. Peradilan Keluarga (Family Court) juga dikenal di negara-negara lain, seperti Australia, Amerika, Inggris, India, Hongkong. Peradilan keluarga tersebut menyidangkan khusus perkara-perkara keluarga.

Pemerintahan Indonesia mengakui keberadaan 6 (enam) Agama yaitu Islam, Kristen Katolik, Kristen Protestan, Budha, Hindu, Kong $\mathrm{Hu} \mathrm{Cu}$ dan kepercayaan lainnya. Dengan adanya pengakuan tersebut, maka timbul ambigu bahwa Peradilan Agama hanya dikhususkan bagi umat muslim. Bila memang pemerintah mengakui agama-agama lain selain Islam, maka Peradilan Agama harus bisa mengakomodasi urusan semua agama yang diakui. Untuk itu solusi jalan tengah yaitu dengan membentuk Peradilan 
Keluarga yang khusus mengadili permasalahan keluarga. Lagipula dengan membentuk Peradilan Keluarga akan mempertegas kompetensi absolut untuk mengadili suatu perkara yang berkaitan dengan urusan keluarga. Dengan adanya kekhususan tersebut, maka semua perkara yang menyidangkan permasalahan keluarga dapat dilimpahkan kepada Peradilan Keluarga sehingga meringankan beban Peradilan Umum yang hampir menangani semua perkara baik pidana umum, pidana khusus, perdata umum dan perdata khusus.

\section{DAFTAR PUSTAKA}

Badan Pusat Statistik. (2015). Nikah, Talak dan Cerai, serta Rujuk (20122015). Retrieved July 7, 2017, from

https://www.bps.go.id/linkTableDinamis/view/id /893Friedman, L. (1984). American Law. New York: W.W.Norton \& Company.Jaya, A. (2009).

Sejarah Pengadilan Agama. IAIN Raden Fatah Palembang.Lisdiyono, E. (2016).

Akuntabilitas Mahkamah Agung. Jakarta: Rajawali Pers.Mertokusumo, S. (2002). Hukum Acara Perdata. Yogyakarta:

Liberty.Rawls, J. (2001). Keadilan dan Demokrasi Telaah Demokrasi. Yogyakarta: Kanisius. 